\title{
Morphometry, Topography and Arterial Supply of the Thyroid Gland in Brazilian Shorthair Cats
}

\author{
Anieli Vidal Stocco ${ }^{1}$, Shirley Viana Peçanha ${ }_{\odot}^{1}$, Renata Medeiros Nascimento ${ }^{1}$, \\ Carlos Augusto dos Santos-Sousa ${ }_{\odot}^{2}$, Paulo Souza-Junior ${ }_{\odot}^{3}{ }^{3}$ Marcelo Abidu-Figueiredo $_{\odot}{ }^{1}$
}

\begin{abstract}
Background: Thyroid gland diseases are the most common endocrinopathies in feline practice. Diagnosis and surgical treatment must base on solid anatomical knowledge about the gland size, localization, and blood supply. However, some textbooks provide a general anatomical description of the thyroid gland of domestic carnivores. Thus, specific details of the feline gland are missing. The present study aimed to investigate the dimensions, topography, and arterial supply of the thyroid gland in Brazilian shorthair cats and, therefore, provide additional data to diagnose and treat feline thyroid diseases. Materials, Methods \& Results: Thirty Brazilian shorthair cats formalin-fixed cadavers (15 male and 15 female) were injected with red-stained latex solution by a canula in the thoracic aorta. The necropsy unit of the Rural Federal University of Rio de Janeiro donated the specimens. The study included only adult animals with no history of thyroid disease. After the fixation period, the cadavers were dissected to investigate the measurements (length, width at cranial and caudal poles, and thickness), topography, and in situ arterial supply of the thyroid lobes. The mean measurements of the length, cranial pole width, caudal pole width, and thickness in the right lobe were $19.39 \pm 3.10 \mathrm{~mm}, 5.36 \pm 1.40 \mathrm{~mm}, 3.67 \pm 0.93 \mathrm{~mm}$, and $1.30 \pm 0.29 \mathrm{~mm}$, respectively; and $20.29 \pm 3.35 \mathrm{~mm}, 4.85 \pm 1.58 \mathrm{~mm}, 3.88 \pm 0.91 \mathrm{~mm}, 1.64 \pm 0.65 \mathrm{~mm}$ in the left lobe, respectively. There were no statistical differences $(P>0.05)$ in the comparison of the measures between sexes or antimers (sides). Pearson's linear correlation detected a positive, moderate $(\mathrm{r}=0.55)$, and significant $(P<0.05)$ correlation between the right and left lobe lengths. In $70 \%$ of the cats, both left and right lobes had the cranial poles located at the same level. Typically, the lobes extended between the first to the eighth tracheal ring. However, the cranial pole of some lobes located as cranially as the cricoid cartilage level, and the caudal pole as caudally as the 12th tracheal ring. Fifty-six percent of the cats had a ventrally located isthmus. In all the sampling, one single thyroid artery emerged as a branch of the common carotid artery and provided branches directly to the thyroid lobe, isthmus and the adjacent muscles and esophagus.

Discussion: Besides establishing average dimensions of normal thyroid lobes in Brazilian shorthair cats, this study detected no significant difference between the average measurements of right and left lobes. Also, a positive linear correlation between the length and width of the right and left lobes became evident. Therefore, the practitioner must consider suspicious any length asymmetry between right and left thyroid lobes until further endocrine test proves otherwise. Most of the cats had the right and left thyroid lobe positioned at the same transversal level; however, positional asymmetries are not uncommon. Unlike dogs, Brazilian shorthair cats have only a single artery to supply each lobe: the thyroid artery. In a feline thyroidectomy, the surgeon must avoid blindly ligating the thyroid artery since this vessel also provided numerous branches to adjacent muscles and esophagus. In a bilateral thyroidectomy, the ventral region between lobes should be thoroughly inspected for the common presence of an isthmus. Sometimes, the surgeon may need to extend the incision caudally beyond the 12th tracheal ring level to visualize the gland tissue entirely.
\end{abstract}

Keywords: endocrinology, feline anatomy, morphometrics, thyroidectomy.

DOI: $10.22456 / 1679-9216.114452$ 


\section{INTRODUCTION}

Cat domestication started about 10,000 years ago and, in many countries, has become more popular than dogs as a pet $[18,24]$. This domestication process has contributed to an increased presence of cats in clinical practice. Some textbooks may provide inaccurate descriptions of cats anatomy because they consider dogs and cats together as domestic carnivores without considering morphological specificities $[8,14]$.

The thyroid is one of the most significant endocrine glands, because it hormones regulate growth and development, metabolic activity, and sensitivity toward other biologically active substances $[11,22]$.

Hyperthyroidism is the most common endocrine disease in cats. Treatment of hyperthyroidism includes pharmacological and surgical modalities [16]. Thyroidectomy offers a potentially definitive cure for hyperthyroidism and is widely done in small animal practice [7]. However, according to Naan et al. [19], ectopic hyperplastic thyroid tissue in some cats requires additional care during the surgical procedure, thereby denoting the importance of structural and topographic knowledge of this region. Also, animals with this condition may present increased vascularization of the thyroid gland [1].

In this context, basic studies that clarify the morphology, topography, and vascularization of the thyroid gland in felines become applicable in the clinical and surgical management of hyperthyroidism in cats. This research aimed to detail the measurements, topography, and vascularization of the thyroid gland in Brazilian shorthair cats to contribute to gross anatomy and feline medicine and surgery.

\section{MATERIALS AND METHODS}

\section{Animals}

The anatomical dissections were performed in 30 cadaveric adult Brazilian shorthair cats in the Laboratory of Teaching and Research in Morphology of Domestic and Wild Animals at the Federal Rural University of Rio de Janeiro: 15 males and 15 females, with the mean rostrum-sacral lengths of $48.25 \pm 0.56$ $\mathrm{cm}$ and $45.19 \pm 0.70 \mathrm{~cm}$, respectively. The university's necropsy unit donated the cadavers. The study included only adult cats with no history/signs of thyroid disease.

\section{Anatomical procedures}

The removal of the sixth and seventh ribs of the cadavers allowed a thoracic aperture to dissect and cannulate the thoracic aorta in situ. The specimens had their vascular system washed with saline solution and, then, were fixed with $10 \%$ formaldehyde. Immediately afterward, a colored stained Petrolátex S- $65^{1}$ was injected inside the aorta to highlight the arteries.

Then, each cadaver stayed in a low-density polyethylene cardboard box with a capacity of $500 \mathrm{~L}$ containing a $10 \%$ formaldehyde solution for 5 days to complete the fixation and latex polymerization process. After this period, a ventral midline incision on the skin and fascia exposed the ventral muscles of the neck, followed by the trachea, thyroid glands, and arteries related to the glands. The thyroid glands and its related arteries were in situ dissected to characterize the topography.

A digital caliper ${ }^{2}$ (Digital Caliper Starret 798) measured the length, width (at both cranial and caudal poles), and thickness of thyroid glands. The photomacrographs were taken by using a Nikon Coolpix L820 model camera ${ }^{3}$. The terminology of this study followed the International Committee on Gross Anatomical Nomenclature [13].

\section{Statistical analysis}

The mean and standard deviation of the thyroid measurements were calculated and compared in both antimeres and sexes by the unpaired $t$-test. Pearson's linear correlation coefficients demonstrated the level of correlation between the right and left measurements. A value of $P<0.05$ was considered statistically significant. BioEstat $5.0^{\circledR}$ software $^{4}$ calculated the statistical analyses and plotted the graphs.

\section{RESULTS}

The average measurements of the length, cranial pole width, caudal pole width, and thickness in the right lobes were $19.39 \pm 3.10 \mathrm{~mm}, 5.36$ $\pm 1.40 \mathrm{~mm}, 3.67 \pm 0.93 \mathrm{~mm}$, and $1.30 \pm 0.29 \mathrm{~mm}$, respectively; and $20.29 \pm 3.35 \mathrm{~mm}, 5.03 \pm 1.29 \mathrm{~mm}$, $3.88 \pm 0.91 \mathrm{~mm}, 1.64 \pm 0.65 \mathrm{~mm}$ in the left lobes, respectively. The averages of the measurements, separated by sex and antimers, are listed in Table 1 . There were no significant differences in the average measurements of the lobes between sexes (Table 1) or antimers (Table 2).

Pearson's linear correlation coefficient revealed a positive, moderate and significant correlation between the lengths of the left and right lobes ( $\mathrm{r}=0.55, P=0.002)$ and between the cranial poles' width of left and right lobes $(\mathrm{r}=0.54, P=0.002)$ [Figure 1]. The correlation between rostrum-sacral 
and right or left lobe lengths was weak and not significant $(-0.40<\mathrm{r}<0.40, P>0.05)$. Also, there was no significant linear correlation among other measurements.

Most of the lobes had the cranial pole at the level of the first tracheal ring and the caudal lobe at the eighth tracheal ring (Table 3). However, the cranial pole of some lobes located as cranially as the cricoid cartilage level, and the caudal pole as caudally as the 12th tracheal ring. In most of the samples (70\%), both left and right lobes had the cranial poles symmetrically located at the same tracheal ring level. The isthmus was apparent in $66 \%$ of male and $46 \%$ of female cats of our sample. One thyroid artery irrigated each lobe in every dissected cat of this sampling (Figure 2). The thyroid artery, always a branch from the common carotid artery, originated some branches to the thyroid gland lobe and a variated number of branches to the adjacent muscles and esophagus (Table 4). Besides irrigating the thyroid lobe, most of the thyroid arteries dissected in this sampling provided braches to sternohyoid, sternothyroid and cricothyroid muscles.

Table 1. Average and standard deviation of the measurements of the lobes of the thyroid glands in Brazilian shorthair cats $(\mathrm{n}=30)$, separated by sex.

\begin{tabular}{ccccc}
\hline Parameter & Total $(\mathrm{n}=30)$ & Male $(\mathrm{n}=15)$ & Female $(\mathrm{n}=15)$ & $P$-value \\
\hline Length of the right lobe & $19.39 \pm 3.10$ & $19.57 \pm 2.77$ & $19.19 \pm 3.41$ & 0.740 \\
Length of the left lobe & $20.29 \pm 3.35$ & $21.36 \pm 3.63$ & $19.23 \pm 2.75$ & 0.080 \\
Width of the right cranial pole & $5.36 \pm 1.40$ & $5.64 \pm 1.20$ & $5.12 \pm 1.51$ & 0.308 \\
Width of the left cranial pole & $5.03 \pm 1.29$ & $5.24 \pm 1.45$ & $4.96 \pm 0.94$ & 0.527 \\
Width of the right caudal pole & $3.67 \pm 0.93$ & $3.86 \pm 1.12$ & $3.44 \pm 0.64$ & 0.218 \\
Width of the left caudal pole & $3.88 \pm 0.91$ & $3.79 \pm 0.87$ & $3.76 \pm 0.88$ & 0.918 \\
Thickness of the right lobe & $1.30 \pm 0.29$ & $1.42 \pm 0.32$ & $1.32 \pm 0.13$ & 0.462 \\
Thickness of the left lobe & $1.64 \pm 0.65$ & $1.97 \pm 0.75$ & $1.31 \pm 0.30$ & 0.054 \\
\hline
\end{tabular}

The $P$-value refers to comparing the averages of measurements between males and females in the Student's $t$-test.

Table 2. $P$-values of Student's $t$-test comparing the average of the measurements of the lobes of the thyroid glands of Brazilian shorthair cats between antimers, of the total sampling and separated by sex.

\begin{tabular}{cccc}
\hline Parameter & Total $(\mathrm{n}=30)$ & Female $(\mathrm{n}=15)$ & Male $(\mathrm{n}=15)$ \\
\hline Length of the lobe & 0.277 & 0.976 & 0.141 \\
Width of the cranial pole & 0.312 & 0.731 & 0.426 \\
Width of the caudal pole & 0.395 & 0.265 & 0.857 \\
Thickness of the lobe & 0.089 & 0.912 & 0.105 \\
\hline
\end{tabular}

Table 3. Absolute and percentage frequencies of the topographic localization of the cranial and caudal poles of the thyroid glands lobes related to cricoid cartilage (CC) or tracheal rings (TR), separated by sex.

\begin{tabular}{|c|c|c|c|c|}
\hline \multirow{2}{*}{ Cranial and caudal levels of the thyroid lobes } & \multicolumn{2}{|c|}{ Male $(\mathrm{n}=15)$} & \multicolumn{2}{|c|}{ Female $(\mathrm{n}=15)$} \\
\hline & Right & Left & Right & Left \\
\hline$C C$ to $5^{\text {th }} T R$ & $2(13.3 \%)$ & - & $2(13.3 \%)$ & $1(6.6 \%)$ \\
\hline$C C$ to $6^{\text {th }} T R$ & $1(6.6 \%)$ & $3(20.0 \%)$ & $2(13.3 \%)$ & $3(20.0 \%)$ \\
\hline CC to $7^{\text {th }} T R$ & - & $1(6.6 \%)$ & - & - \\
\hline CC to $8^{\text {th }} T R$ & $1(6.6 \%)$ & $1(6.6 \%)$ & - & $1(6.6 \%)$ \\
\hline CC to $9^{\text {th }} T R$ & $3(20.0 \%)$ & - & $1(6.6 \%)$ & $1(6.6 \%)$ \\
\hline $1^{\text {st }} T R$ to $5^{\text {th }} T R$ & $1(6.6 \%)$ & - & $1(6.6 \%)$ & - \\
\hline $1^{\text {st }} T R$ to $6^{\text {th }} T R$ & - & - & - & $1(6.6 \%)$ \\
\hline $1^{\text {st } T R}$ to $7^{\text {th }} T R$ & $1(6.6 \%)$ & - & $3(20.0 \%)$ & $2(13.3 \%)$ \\
\hline $1^{\text {st }} T R$ to $8^{\text {th }} T R$ & $2(13.3 \%)$ & $3(20.0 \%)$ & $3(20.0 \%)$ & $5(33.3 \%)$ \\
\hline $1^{\text {st }} T R$ to $9^{\text {th }} T R$ & $1(6.6 \%)$ & $1(6.6 \%)$ & $3(20.0 \%)$ & $1(6.6 \%)$ \\
\hline $1^{\text {st }} \mathrm{TR}$ to $10^{\text {th }} \mathrm{TR}$ & $2(13.3 \%)$ & $1(6.6 \%)$ & - & - \\
\hline 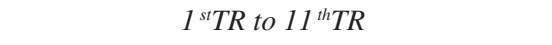 & - & $1(6.6 \%)$ & - & - \\
\hline $1^{\text {st }} \mathrm{TR}$ to $10^{\text {th }} \mathrm{TR}$ & - & $1(6.6 \%)$ & - & - \\
\hline $2^{\text {nd }} T R$ to $11^{\text {th }} T R$ & $1(6.6 \%)$ & $1(6.6 \%)$ & - & - \\
\hline $2^{\text {nd }} T R$ to $12^{\text {th }} T R$ & - & $1(6.6 \%)$ & - & - \\
\hline $3^{\text {rd }} T R$ to $7^{\text {th }} T R$ & - & $1(6.6 \%)$ & - & - \\
\hline
\end{tabular}


A.V. Stocco, S.V. Peçanha, R.M. Nascimento, et al. 2021. Morphometry, Topography and Arterial Supply of the Thyroid Gland in Brazilian Shorthair Cats.

Acta Scientiae Veterinariae. 49: 1828.

Table 4. Absolute and percentage frequencies of the right and left extrathyroid branches of the thyroid artery in Brazilian shorthair cats $(n=30)$, separated by sex and antimers.

\begin{tabular}{ccccc}
\hline \multirow{2}{*}{ Extrathyroid branches } & \multicolumn{2}{c}{ Male $(\mathrm{n}=15)$} & \multicolumn{2}{c}{ Female $(\mathrm{n}=15)$} \\
\cline { 2 - 5 } & Right & Left & Right & Left \\
\hline m. sternohyoid & $12(80.0 \%)$ & $09(60.0 \%)$ & $11(73.3 \%)$ & $08(53.3 \%)$ \\
m. sternothyroid & $14(93.3 \%)$ & $14(93.3 \%)$ & $14(93.3 \%)$ & $14(93.3 \%)$ \\
m. cricothyroid & $14(93.3 \%)$ & $07(46.6 \%)$ & $11(73.3 \%)$ & $09(60.0 \%)$ \\
m. thyrohyoid & $07(46.6 \%)$ & $05(33.3 \%)$ & $06(40.0 \%)$ & $05(33.3 \%)$ \\
m. sternocephalicus & $01(6.60 \%)$ & - & - & - \\
Esophagus & $07(46.6 \%)$ & $13(86.6 \%)$ & $10(66.6 \%)$ & $11(73.3 \%)$ \\
\hline
\end{tabular}

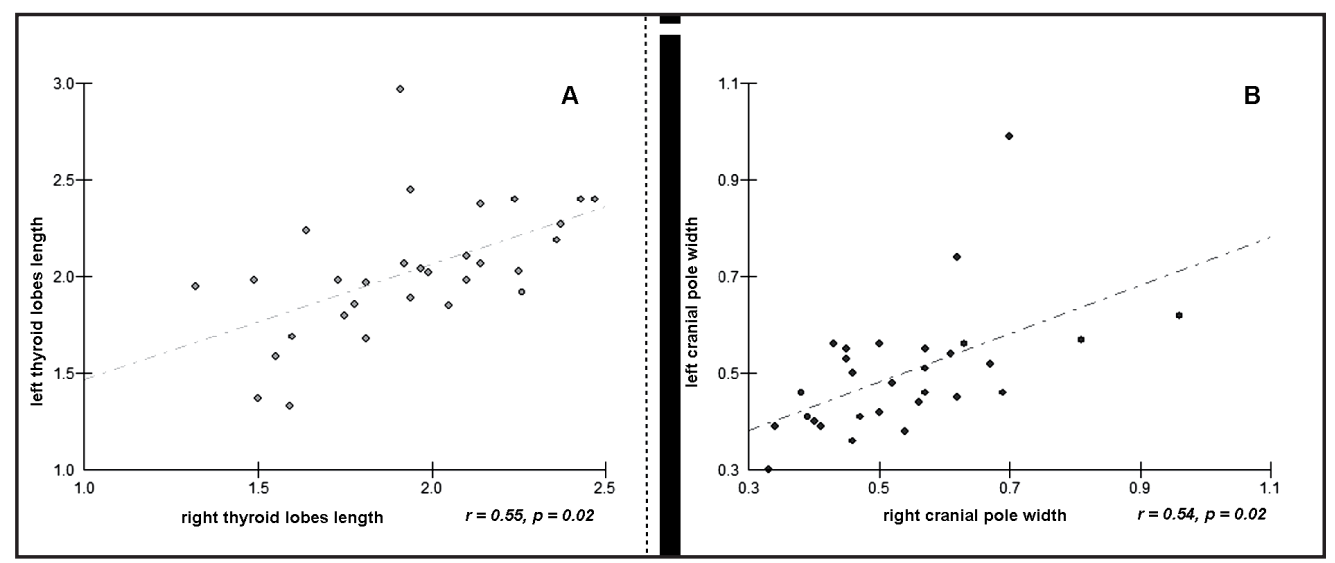

Figure 1. Scatter plots graphs display the relationship between the left and right thyroid lobes length (A) and cranial poles width (B). The lower-left-to-upper-right pattern in both graphs indicates a positive, moderate, and significant Pearson linear correlation between the variables.

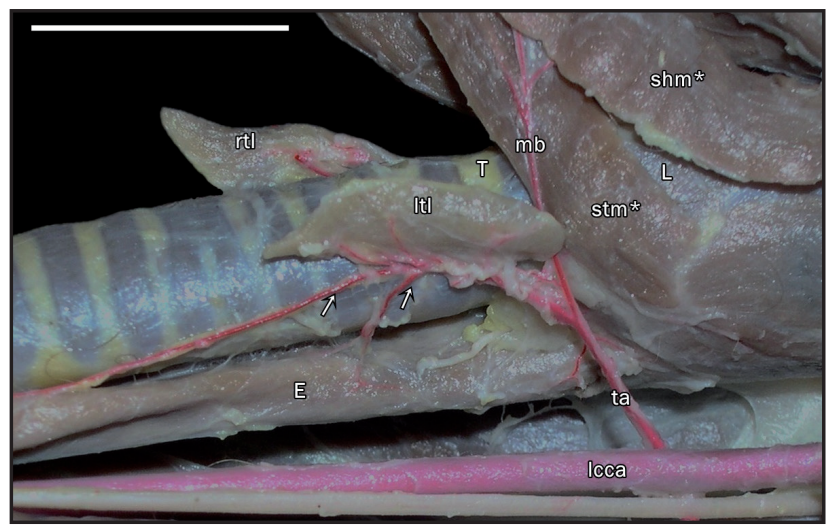

Figure 2. Photomacrography of the left lateral view of the dissected cervical region from an adult, female, Brazilian shorthair cat showing the left lobe of the thyroid gland and its arterial irrigation and adjacent structures. E: esophagus; L; larynx; lcca: left common carotid artery; ltl: left thyroid lobe; mb: musculary branches; rtl: right thyroid lobe; shm*: sternohyoid muscle (sectioned); stm*: sternothyroid muscle (sectioned); T: trachea; ta: thyroid artery; Arrows: esophageal branches. [Bar= $20 \mathrm{~mm}$ ]. 


\section{DISCUSSION}

Data on morphometry, topography, and vascularization of the thyroid gland in domestic cats are scarce and usually presented without distinguishing from dogs. However, according to the literature [2] determined that each lobe is $12.0-15.0 \mathrm{~mm}$ long, $2.0-10.0 \mathrm{~mm}$ wide, and $1.5-4.0 \mathrm{~mm}$ thick in cats. The size of a single lobe in cats is approximately 20.0 $\mathrm{mm}$ in length and $3.0 \mathrm{~mm}$ in width. The lobes are approximately $10 \mathrm{~mm}$ in length and $3-5 \mathrm{~mm}$ in width $[9,29]$. In the present study, the average length of the thyroid lobes in Brazilian shorthair cats varied from 19.19 to $21.36 \mathrm{~mm}$, which diverged from some of these previous descriptions. The width and thickness measurements were similar to those reported in the literature $[2,9,29]$. This data is relevant because it can help the feline practitioner judging if a thyroid gland has an acceptable size. Thyroid enlargements might request a further investigation based on hormonal level measurements or biopsy.

In the present study sample, there were no significant differences in the average measurements between sexes or antimers, which was an expected finding since only a few studies reported asymmetries in lobe sizes. The length and width of the left lobe in dogs, regardless of gender, was greater in a study using ultrasound examination [21]. In European bovines fetuses, the left lobe has a greater width than the right [27]. In the same study, the average length of the left lobe was higher in males than in females [27]. In New Zealand rabbits, the mean thickness of the right lobe in females was higher than those of males, and the length of the left lobe in females was higher than the right [28]. Thus, asymmetries between the sizes of the lobes of the thyroid gland in cats may be suspicious until deepening an investigation by additional tests. Furthermore, the positive and significant linear correlation between left and right lobes length and cranial poles' width reinforces that asymmetries in lobes sizes are unusual in Brazilian shorthair cats till proven otherwise. The weak correlation between rostrum-sacrum length and lobes length highlighted that longer cats do not necessarily have longer thyroid lobes.

Palpation of the thyroid gland is essential for the early diagnosis of feline hyperthyroidism and, thus, to prevent severe systemic signs of the disease [23]. That way, the accurate understanding of the thyroid gland's anatomical topography and landmarks is also relevant for the clinician and to further surgical access.

The thyroid gland in Brazilian shorthair cat was located ventrolateral to the trachea, which is similar to that observed in dogs [15], jaguarundi cat [6], New Zealand rabbits [4], rats [30], rabbit [33], and domestic ungulates [14], except for pigs who have a thick and compacted glandular tissue on the ventral surface of the trachea [14].

Cartee et al. [5] studied ultrasound images of 10 adult cats and reported that the thyroid glands localized about $12 \mathrm{~mm}$ from the laryngeal opening, and the cranial pole of the gland was at the junction of the cricoid and thyroid cartilages. Each lobe lies lateral to the larynx and trachea, ventral to the esophagus, medial to the carotid sheath, and dorsal to the sternothyroid muscle [5]. The caudal limit of the lobes in cats ends at the level of the seventh to the tenth tracheal rings, which coincides with our observation. In Brazilian shorthair cats, we found lobes that extended caudally to the level of the 12th ring in some males [2].

Some surgery textbooks generically revise the surgical anatomy of the thyroid gland describing the left lobe as often caudally located to the right lobe $[3,10]$. This information might be correct for dogs [12] but does not for cats. In the Brazilian shorthair cats, 21 (70\%) animals had the cranial poles of both lobes at the same transversal level, and only $6(20 \%)$ had the left cranial pole located caudally, and $3(10 \%)$ had the right cranial pole situated caudally.

The thyroid gland of different species of diprotodonts was always located ventrolaterally between the larynx and the trachea. However, in koalas, they were arranged laterally to the trachea, at the level of the clavicle [35].

In a study of 60 specimens ( 30 males and 30 females) of Cavia cobaya [32], the presence of long, ellipsoid-looking thyroid lobes, which were located laterally to the trachea, showed a uniform morphology. However, only 6 males and 7 females had an isthmus.

The isthmus is often present in cats, has glandular tissue and measures only 1 or $2 \mathrm{~mm}$ [2]. Most of the Brazilian shorthair cats $(57 \%)$ had an isthmus (6\% of male and $46 \%$ of female cats of our sample). Thus, in a thyroidectomy, the surgeon might consider removing the isthmus since it is often found in cats and may consist of functional endocrine tissue. 
In 30 New Zealand rabbits, all the animals had an isthmus which established a connection between the cranial and caudal poles of the thyroid gland [4,28]. The absence of the isthmus connecting the thyroid lobes, as observed in a part of the Brazilian shorthair cats, was also reported in diprotodont marsupials [35], house musk shrew [34], and polyprotodont marsupials [31]. In these marsupials, the author mentioned that the presence of the isthmus was rare.

The present sample revealed the right and left lobes to have a varied topography between males and females. These findings are similar to those described in New Zealand rabbits, which mainly presented the cranial pole beginning at the cricoid cartilage and the first tracheal ring [28]. However, a slight variation in the topography of the caudal pole of males was recorded because some specimens had it located at the level of th 12th tracheal ring. Thus, the surgeon must be concerned about the eventual necessity of extending the incision caudally to achieve a complete exposure of the lobes tissues.

Some textbooks of small animal surgery generically describe the thyroid gland as irrigated by a cranial thyroid artery, as a branch of the common carotid artery, and caudal thyroid artery, as a branch of the brachiocephalic trunk [10]. These texts also mention that the caudal thyroid artery is often absent in cats [10]. In every dissected Brazilian shorthair cat, there was only a single artery responsible for the arterial supply of each thyroid lobe: the thyroid artery, which was a branch of the common carotid artery. It coincides with some of the first descriptions in the domestic cats that reported the thyroid artery enters the lobe at its cranial pole and gives off several small branches $[20,29]$. The feline's thyroid artery corresponds to the superior thyroid artery of other species, as the caudal (inferior) thyroid artery is lacking in the cat [10]. The term "cranial" thyroid artery in the cat seems doubtful since there is no "caudal" thyroid artery in this species. Thus, the most appropriate nomenclature in cats would be just the "thyroid artery."

The thyroid artery was a direct branch of the common carotid artery in New Zealand rabbits, too $[4,28]$. However, both cranial and caudal thyroid arteries irrigated the thyroid glands of some other species, as described in dogs [12,26], jaguarondi [6], and ruminants $[15,27]$.
In Brazilian shorthair cat, different branches arose from the thyroid artery to the muscles sternocephalic, sternohyoid, sternothyroid, cricothyroid, thyrohyoid, and esophagus. These branches were reported mainly in thyroid vascularization studies $[30,35]$. In rats, the cranial and caudal thyroid arteries supply the thyroid gland; however, these vessels were both mainly originated from the external carotid artery [30].

Yamazaki [32] identified 5 types of irrigation to the thyroid gland in guinea pigs, including quantitative variations. Nonetheless, the author observed the cranial thyroid artery to be the most frequent, especially in males. In Brazilian shorthair cats, the thyroid artery was the single vessel to provide blood supply to the thyroid gland lobes in the 30 dissected individuals.

Understanding the vascularization of the thyroid gland is a requirement both for diagnosis and treatment [16]. A study of pre-and post-treatment of hyperthyroidism revealed an increase in the vascularization of the thyroid gland through ultrasound Doppler evaluation before the clinical treatment [1]. After 6 months of treatment, the authors detected a decrease in vascularization of the thyroid lobes [1].

The thyroidectomy in cats offers a potentially permanent cure for hyperthyroidism without requiring sophisticated equipment, making it widely available in general practice [7]. Common complications of thyroid surgery include intraoperative hemorrhage [25]. Therefore, information on the topography and vascularization of the thyroid gland in cats facilitates the surgical approach of this gland, besides supporting applied studies $[1,7,16,19]$. Based on our sample, in feline thyroidectomy, only terminal branches to the thyroid lobes must be cautiously occluded to remove the gland, and the surgeon must avoid ligating the muscular or esophageal branches at risk to impair the irrigation of other organs.

In terms of comparative anatomy, dissection of other breeds of domestic cats and other felid species can clarify if a single thyroid artery to each lobe is a typical phylogenetic trait of this family or a particular finding of Brazilian shorthair cats.

\section{CONCLUSION}

The practitioner should suspect when a feline thyroid lobe is larger or lesser than $20 \mathrm{~mm}$ in length or if one lobe is more prominent than the other. In these 
cases, further investigation by endocrine tests might be necessary to clarify an endocrinopathy. The single artery that supplies each lobe might be appropriately named thyroid artery because, unlike dogs, there were no cranial and caudal thyroid arteries in Brazilian shorthair cats. In a thyroidectomy, surgeons must carefully ligate the small direct braches to the lobe without injuring the numerous other branches to the nearby muscles and esophagus. Further studies on other felid species can clarify if a single thyroid artery to each lobe is a typical phylogenetic trait of this family.

\section{MANUFACTURERS}

${ }^{1}$ Petróleo Brasileiro S.A Petrobras. Duque de Caxias, RJ, Brazil.

${ }^{2}$ L.S. Starrett Company. Athol, MA, U.S.A.
${ }^{3}$ Nikon Corporation. Tokyo, Japan.

${ }^{4}$ Instituto de Desenvolvimento Sustentável Mamirauá. Belém, PA, Brazil.

Acknowledgments. The present work was done with Support for Higher Level Personnel Perfectioning Coordination - Brazil (CAPES) - Financing 001; Research Support Foundation of the State of Rio de Janeiro - FAPERJ and National Council for Scientific and Technological Development - CNPq.

Ethical approval. The research ethics committee of Rio de Janeiro Federal Rural University approved this study (23083.005334/2009-49).

Declaration of interest. The authors declared no potential conflicts of interest with respect to the research, authorship, and/ or publication of this article. The authors alone are responsible for the content and writing of paper.

\section{REFERENCES}

1 Barberet V., Baeumlin Y., Taeymans O., Duchateau L., Peremans K., Van Hoek I., Daminet S. \& Saunders J.H. 2010. Pre- and post-treatment ultrasonography of the thyroid gland in hyperthyroid cats. Veterinary Radiology \& Ultrasound. 51(3): 324-330. DOI: doi.org/10.1111/j.1740-8261.2009.01656.x

2 Barone R. \& Simoens P. 2010. Glandes Endocrines. In: Anatomie Comparée de Mammifères Domestiques: Neurologie II. Paris: Vigot, pp.415-428.

3 Birchard S. J. \& Brito Galvão J.F. 2014. Thyroidectomy in the Dog and Cat. In: Bojrab M.J. (Ed). Current Techniques in Small Animal Surgery. 5th edn. Jackson: Teton Newmedia, pp.558-563.

4 Borges A.P.S., Menezes L.T., Santos L.A., Herrera G.C., França G.L., Paula S.Y.A., Hiraki K.R.N \& Silva F.O.C. 2019. Topography, irrigation, and histology of the thyroid gland of New Zealand rabbits (Oryctolagus cuniculus Linnaeus, 1758). International Journal of Advanced Engineering Research and Science. 6(3): 225-229. DOI: https://doi.org/10.22161/ijaers.6.3.29.

5 Cartee R.E., Bodner S.T.F \& Gray B.W. 1993. Ultrasound Examination of the Feline Thyroid. Journal of Diagnostic Medical Sonography. 9(6): 323-326. DOI: https://doi.org/10.1177/875647939300900606.

6 Carvalho S.F.M., Santos A.L.Q., Andrade M.B., Magalhaes L.M., Ribeiro F.M, Cruz G.C. \& Malta T.S. 2003. Morfometria e vascularização arterial da glândula tireóide do gato mourisco, Herpailurus yagouaroundi (Severtzow, 1858) Felidae. Ars Veterinaria. 19(3): 216-218.

7 Covey H.L., Chang Y.M., Elliott J. \& Syme H.M. 2019. Changes in thyroid and renal function afterbilateral thyroidectomy in cats. Journal of Veterinary Internal Medicine. 33(2): 508-515. DOI: https://doi.org/10.1111/jvim.15450.

8 Dyce K.M., Sack W.O. \& Wersing C.J.G. 2019. Glândulas Endócrinas. In: Tratado de Anatomia Veterinária. 5.ed. Rio de Janeiro: Elsevier, pp.356-358.

9 Flanders J.A. 1994. Surgical therapy of the thyroid. Veterinary Clinics of North America: Small Animal Practice. 24(3): 607-621.

10 Fossum T.W. 2013. Surgery of the Endocrine System. In: Small Animal Surgery. 4th edn. Philadelphia: Elsevier, pp.668-679.

11 Garcia-Reyero N. 2018. The clandestine organs of the endocrine system. General and Comparative Endocrinology. 257: 264-271.

12 Hullinger R. L. 2020. The Endocine System. In: Hermanson J.W., De Lahunta A., Miller H.E. \& Miller E. (Eds). Anatomy of the Dog. 5th edn. St. Louis: Elsevier, pp.412-416.

13 International Committee on Veterinary Gross Anatomical Nomenclature. 2017. Nomina Anatomica Veterinaria. 5th edn. Hanover: Editorial Committee, pp.64-65.

14 König H.E. \& Liebich H.G. 2016. Gândulas Endócrinas. In: Anatomia dos Animais Domésticos: Texto e Atlas Colorido. 6.ed. Porto Alegre: Artmed, pp.571-575.

15 Lima E.M.M., Ferreira P.M., Silva L.R.E, Vianna A.R.C.B., Santana M.I.S., Silva F.O.C.E. \& Severino R.S. 2009. Morfometria e suprimento arterial da glândula tireoide em ovinos da raça Santa Inês. Veterinária Notícias. 15(1): 35-40. 
16 Loftus J.P., Derosa S., Struble A.M., Randolph J.F. \& Wakshlag J.J. 2019. One-year study evaluating efficacy of an iodine-restricted diet for the treatment of moderate-to-severe hyperthyroidism in cats. Veterinary Medicine. 10: 9-16. DOI: 10.2147/VMRR.S189709.

17 Lovelace K. 2009. Comparing thyroid palpation techniques. Journal of Feline Medicine and Surgery. 11(6): 525-526. DOI:10.1016/j.jfms.2009.02.002.

18 Montague M.J., Gandolfi B., Khan R., Aken B.L., Searle S.M., Minx P., Hillier L.W., Koboldt D.C., Davis B.W., Driscoll C.A., Barr C.S., Blackistone K., Quilez J., Lorente-Galdos B., Marques-Bonet T., Alkan C., Thomas G.W., Hahn M.W., Menotti-Raymond M., Brien S.J., Wilson R.K., Lyons L.A., Murphy W.J. \& Warren W.C. 2014. Comparative analysis of the domestic cat genome reveals genetic signatures underlying feline biology and domestication. Proceedings of the National Academy of Sciences. 111(48): 17230-17235. DOI: 10.1073/pnas.1410083111.

19 Naan E.C., Kirpensteijn J., Kooistra H.S. \& Peeters M.E. 2006. Results of Thyroidectomy in 101 Cats with Hyperthyroidism. Veterinary Surgery. 35(3): 287-293. DOI:10.1111/j.1532-950x.2006.00146.x.

20 Nicholas J. S. \& Swingle W.W. 1925. An experimental and morphological study of the parathyroid glands of the cat. American Journal of Anatomy. 34(3): 469-509. DOI: doi:10.1002/aja.1000340304.

21 Novo A.C.M.P., Carvalho C. \& Alves R.B.M. 2009. Ultrassonografia das glândulas tireóideas em cães (Canis familiaris, Linnaeus, 1758). Jornal Brasileiro de Ciência Animal. 2(3): 135-149.

22 Nussey S. \& Whitehead S. 2001. The thyroid gland. In: Endocrinology: An Integrated Approach. Oxford: BIOS Scientific Publishers, pp.2-11.

23 Paepe D., Smets P., Van Hoek I., Saunders J., Duchateau L. \& Daminet S. 2008. Within- and between-examiner agreement for two thyroid palpation techniques in healthy and hyperthyroid cats. Journal of Feline Medicine and Surgery. 10(6): 558-565. DOI: 10.1016/j.jfms.2008.03.009.

24 Plitman L., Cern A.P., Farnworth M.J., Packer R.M.A. \& Gunn-Moore D.A. 2019. Motivation of Owners to Purchase Pedigree Cats, with Specific Focus on the Acquisition of Brachycephalic Cats. Animals. 9(7): 1-18. DOI: 10.3390/ani9070394.

25 Radlinsky M.G. 2007. Thyroid surgery in dogs and cats. Veterinary Clinics of North America: Small Animal Practice. 37(4): 789-798.

26 Rodrigues A.B.F., Costa N.Q., Aguiar R.R., Di Filippo P.A. \& Almeida AJ. 2016. Análise morfológica, topográfica e vascularização da glândula tireóide em cães (Canis familiaris). Revista Brasileira de Medicina Veterinária. 38(3): 316-322.

27 Santos A.L.Q., Maximiano-Neto A., Moura L.R., Pereira H.C. \& Silva Júnior L.M.D.A. 2008. Vascularização arterial, forma, topografia e morfometria da glândula tireóide em fetos de bovinos com sangue europeu. Veterinária Notícias. 14(1): 63-70.

28 Silva S.C., Stocco A.V., Santos Sousa C.A., Estruc T.M., Marques L.E., Souza-Junior P. \& Abidu-Figueiredo M. 2019. Morphometry and vascularization of the thyroid glands in rabbits (Oryctolagus cuniculus). International Journal of Morphology. 37(4): 1404-1408.

29 Volckaert V., Vandermeulen E., Daminet S., Saunders J. \& Peremans K. 2016. Hyperthyroidism in cats, part I: anatomy, physiology, pathophysiology, diagnosis and imaging. Vlaams Diergeneeskd Tijdschr. 85(5): 255-264. DOI: 10.21825/vdt.v85i5.16317.

30 Yamasaki M. 1990. Comparative anatomical studies of thyroid and thymic arteries: I. Rat (Rattus norvegicus albinus). American Journal of Anatomy. 188(3): 249-259. DOI: 10.1002/aja.1001880304.

31 Yamasaki M. 1993. Comparative anatomical studies on the thyroid and thymic arteries. II. Polyprotodont marsupials. Journal of Anatomy. 183(Pt. 2): 359-366.

32 Yamasaki M. 1995. Comparative anatomical studies on the thyroid and thymic arteries. III. Guinea pig (Cavia cobaya). Journal of Anatomy. 186(Pt. 2): 383-393.

33 Yamasaki M. 1996. Comparative anatomical studies on the thyroid and thymic arteries. IV. Rabbit (Oryctolagus cuniculus). Journal of Anatomy. 188(Pt. 3): 557-564.

34 Yamasaki M. 1997. Comparative anatomical studies on the thyroid and thymic arteries. V. House musk shrew (Suncus murinus). Okajimas Folia Anatomica Japonica. 73(6): 293-300. DOI: 10.2535/ofaj1936.73.6_293.

35 Yamasaki M. 2016. Comparative anatomical studies on the thyroid and thymic arteries. VI. Diprotodont marsupials. Anatomical Science International. 91: 258-273. DOI: 10.1007/s12565-015-0293-y 